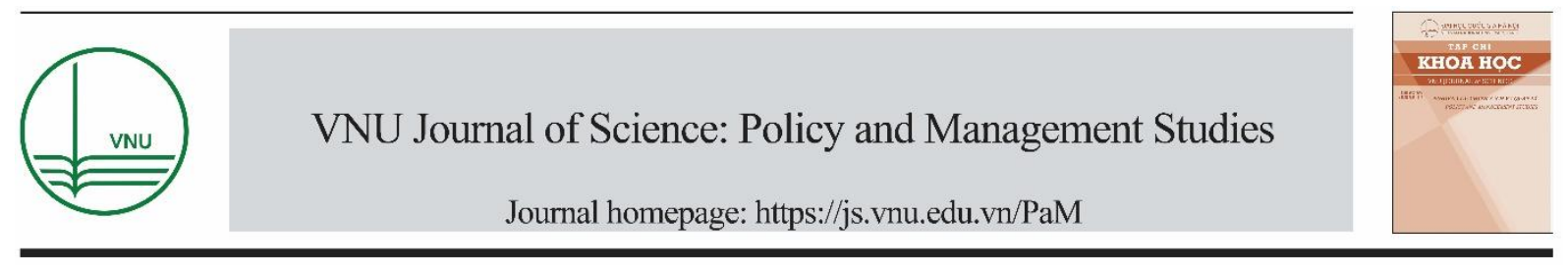

Original Article

\title{
Social-occupational Structure Change in the Mekong Delta
}

\author{
Phan Thuan* \\ Academy of Politics Region IV, No. 6 Nguyen Van Cu Street, Ninh Kieu, Can Tho, Vietnam \\ Received 07 June 2019 \\ Revised 17 June 2019; Accepted 20 June 2019
}

\begin{abstract}
By overview method, the article showed clearly the currently of shifts in social occupational structure in the Mekong Delta. The changes in social structure of jobs in the Mekong Delta is focused on the characters such as labor capability, economic forms, working situation and economic area, which contributes to various characters of shift social structure of jobs. This article presents that this changes has a positive trend such as reducing argiculture, increasing severice and industry field, labour in private and FDI economic forms growth up; working situtation upward to trend. Althought this changes pointed out the slower pace of shifts in comparison to nationwide pace and unstantain. As there was serveral reasons impact on this changes. Thus, this shift had influenced income, social stratification and migration decision of labor in the Mekong Delta. The article also pointed out some evidences about the different income of labor in economic forms and economic area. The author then provided some suggestions on how to facilitate positive shifts in social occupational structure, such as training and resolving jobs policies, linking to between the famers, the scientist, the state and the business man, restructuring economy, promoting policies and environment investment
\end{abstract}

Keywords: Shift, Mekong Delta, economic form, labor migration, occupational structure, shift in occupational structure.

\footnotetext{
* Corresponding author.

E-mail address: phanthuanhv482@gmail.com
}

https://doi.org/10.25073/2588-1116/vnupam.4183 


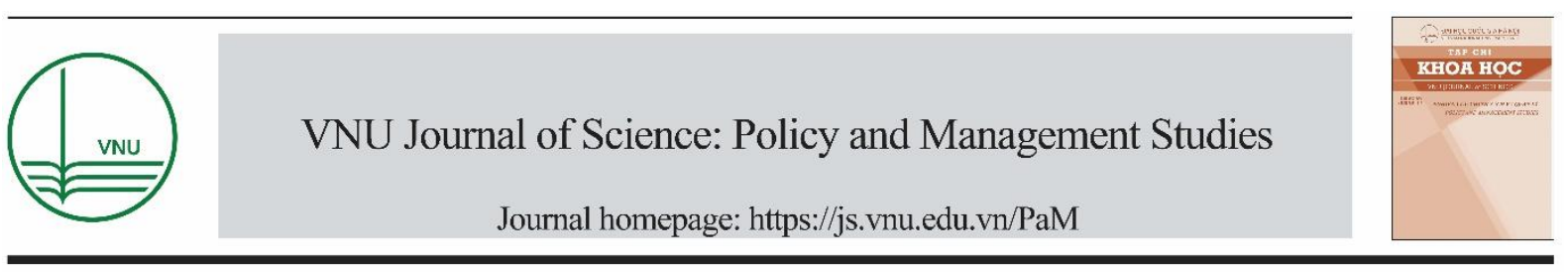

\title{
Biến đổi cơ cấu xã hội- nghề nghiệp ở đồng bằng sông Cửu Long
}

\author{
Phan Thuận* \\ Học viện Chính trị khu vục IV, Số 6 Nguyễn Văn Cù, \\ Quận Ninh Kiều, Thành phố Cần Tho, Việt Nam
}

Nhận ngày 07 tháng 6 năm 2019

Chỉnh sửa ngày 17 tháng 6 năm 2019; Chấp nhận đăng ngày 20 tháng 6 năm 2019

\begin{abstract}
Tóm tắt: Bằng phương pháp phân tích tài liệu, bài viết đã làm rõ thực trạng biến đổi cơ cấu xã hội nghề nghiệp ở đồng bằng sông Cửu Long. Sự biến đổi cơ cấu xã hội nghề nghiệp ở đồng bằng sông Cửu Long được tập trung vào các đặc điểm như trình độ chuyên môn, loại hình kinh tế, vị thế việc làm, khu vực kinh tế. Những đặc điểm này góp phần làm phong phú về đặc trưng trong nghiên cứu về sự biến đổi cơ cấu xã hội nghề nghiệp. Bài viết cho thấy sự biến đổi này có xu hướng tích cực, nông nghiệp giảm, dịch vụ, công nghiệp tăng; lao động tham gia vào các loại hình kinh tế tư nhân và vốn đầu tư nước ngoài tăng lên; vị thế việc làm cũng có xu hướng đó. Mặc dù vậy, sự biến đổi này vẫn còn chậm so với cả nước và thiếu ồn định. Sở dĩ là vì, có nhiều nguyên nhân tác động đến sự biến đổi này. Chính vì thế, sự biến đổi này đã có tác động đến thu nhập, phân tầng xã hội và quyết định di cư của lực lượng lao động ở vùng Đồng bằng sông Cửu Long. Bài viết cũng đã đưa ra nhiều bằng chứng cho sự khác biệt về thu nhập của lực lượng lao động ở các loại hình kinh tế, khu vực kinh tế... Trên cơ sở đó, bài viết đã gợi mở một số khuyển nghị như chính sách đào tạo và giải quyết việc làm, liên kết "bốn nhà", tái cơ cấu trúc kinh tế, cải thiện chính sách và môi trường đầu tư... nhằm góp phần thúc đẩy sự chuyển dịch cơ cấu nghề nghiệp theo hướng tích của vùng.
\end{abstract}

Tù khóa: Biến đổi, Đồng bằng sông Cửu Long, loại hình kinh tế, di cư lao động, cơ cấu nghề nghiệp, chuyển dịch cơ cấu nghề.

\section{1. Đặt vấn đề}

Dưới sự lãnh đạo sáng suốt của Đảng, sau hơn 30 thực hiện đường lối đổi mới, xã hội Việt Nam đã diễn ra một quá trình biến đổi toàn diện, vô cùng to lớn cả tầm vĩ mô và vi mô, cả về kinh tế, chính trị, văn hóa, xã hội... Chính vì sự biến đồi đó đã góp phần đưa "đất nước ta đã ra khỏi khủng hoảng kinh tế- xã hội, có sự thay đổi cơ bản và toàn diện. Kinh tế tăng trưởng khá nhanh,

\footnotetext{
*Tác giả liên hệ.

Địa chỉ email: phanthuanhv482@gmail.com
}

https://doi.org/10.25073/2588-1116/vnupam.4183 
sự nghiệp công nghiệp hóa, hiện đại hóa, phát triển kinh tế thị trường định hướng xã hội chủ nghĩa được đẩy mạnh. Đời sống nhân dân được cải thiện rõ rệt. Hệ thống chính trị và khối đại đoàn kết dân tộc được củng cố và tăng cường. Quốc phòng an ninh được giữ vững. Vị thế nước ta trên trường quốc tế không ngừng nâng cao. Sức mạnh tổng hợp của quốc gia đã tăng lên nhiều, tạo ra thể và lực mới cho đất nước tiếp tục đi lên với triển vọng tốt đẹp" [1, tr.67-68].

Cùng với sự biến đổi chung của cả nước, đồng bằng sông Cửu Long (ĐBSCL) cũng đã có những biển đổi khá rõ nét trên các lĩnh vực kinh tế, chính trị, văn hóa, xã hội... Trong những năm qua, ĐBSCL đã phát huy thế mạnh là lúa gạo trái cây và thủy sản, nhờ đó đã đóng góp khá tích cực vào trong quá trình biến đổi cơ cấu xã hội, trong đó có biến đổi về cơ cấu xã hội- nghề nghiệp. Toàn vùng đã nỗ lực thực hiện chủ trương chuyển dịch cơ cấu kinh tế theo hướng hiện đại, tăng tỷ trọng lao động trong ngành công nghiệp và dịch vụ, giảm tỷ trọng lao động trong ngành nông nghiệp. Mặc dù vậy, cơ cấu lao động nông, lâm và thủy sản của toàn vùng vẫn chiếm đển $47,8 \%$ so với 41,7 của cả nước [2, tr.21-22] và sự chuyển dịch cơ cấu lao động còn chậm so với cả nước, nếu năm 2010 cả nước có 49,5\% lao động hoạt động trong nông lâm thủy sản thì đến năm 2016 chỉ còn $41,7 \%$ (giảm 7,8\%); trong khi đó cơ cấu lao động của vùng hoạt động trong lĩnh vực này chỉ giảm $4,8 \%$. Điều này cho thấy, sự biến đổi cơ cấu xã hội- nghề nghiệp của vùng còn khá chậm so với cả nước và nó có tác động khá mạnh mẽ đến sự phát triển của vùng trong tình hình hiện nay.

Do đó, việc nghiên cứu thực trạng biến đổi cơ cấu xã hội- nghề nghiệp ở ĐBSCL là rất cần thiết, nhằm góp phần nhận diện thực trạng và sự tác động của thực trạng biến đổi này đối với sự phát triển kinh tế- xã hội của vùng. Xuất phát từ ý nghĩa đó, bài viết tập trung phân tích thưc trạng biến đổi cơ cấu xã hội- nghề nghiệp của vùng ĐBSCL và đánh giá sự tác động của biến đổi này đến sự phát triển của vùng; từ đó gợi mở một số khuyến nghị nhằm thúc đầy sự biến đổi cơ cấu cấu- nghề nghiệp của vùng theo hướng tích cực và hiện đại.

\section{Thực trạng biến đổi cơ cấu xã hội- nghề nghiệp ở đồng bằng sông Cửu Long}

Thực hiện đường lối đổi mới do Đảng ta khởi sướng và lãnh đạo, sau hơn 30 năm thực hiện, vùng ĐBSCL đã có những biến đổi cơ cấu xã hội một cách rõ nét, trong đó có biến đổi cơ cấu xã hội- nghề nghiệp. Các nghiên cứu trước đây cho thấy, cơ cấu xã hội - nghề nghiệp ở nhiều giác độ khác nhau. Tác giả Nguyễn Minh Sang (2017) đã phân tích biến đổi cơ cấu xã hội nghề nghiệp ở ĐBSCL chủ yếu tập trung vào cơ cấu hộ nghề nghiệp và cơ cấu lao động theo khu vực kinh tế. Tuy nhiên, cơ cấu xã hội nghề nghiệp không chỉ dừng lại ở những đặc trưng đó mà còn tiếp cận ở nhiều đặc trưng khác. Điều này góp phần làm cho sự đa dạng trong phân tích về cơ cấu xã hội nghề nghiệp ở ĐBSCL. Do đó, sự biến đổi này được thể hiện ở một số khía cạnh như (1) biến đồi cơ cấu xã hội- nghề nghiệp theo trình độ chuyên môn, (2) biến đổi cơ cấu xã hội- nghề nghiệp theo loại hình kinh tế, (3) biến đổi cơ cấu xã hội- nghề nghiệp theo ngành nghề, (4) biến đổi cơ cấu xã hội- nghề nghiệp theo khu vực kinh tế.

\subsection{Biến đổi co cấu xã hội-nghề nghiệp theo trình độ chuyên môn}

Trong những năm gần đây (2009-2016), lực lượng lao động được đào tạo ở ĐBSCL đã có những biến đổi nhất định. Bảng số liệu 2.1 cho thấy, tỷ lệ lao động chưa qua đào tạo và không có bằng chứng chỉ chuyên môn có xu hướng giảm từ $96,4 \%$ của năm 2009 xuống còn $90,8 \%$ của năm 2012 và còn $87,9 \%$ của năm 2016. Tỷ lệ lao động được đào tạo từ sơ cấp nghề trở lên đã tăng lên, trong đó lao động có trình độ đại học trở lên tăng khá nhanh từ $0,4 \%$ của năm 2009 lên 5,5\% của năm 2016. Mặc dù vậy, theo kết quả điều tra lao động và việc làm (2016), ĐBSCL là một trong những vùng có lao động có việc làm được đào tạo chiếm tỷ lệ thấp nhất $(12,0 \%)$ trong cả nước, so với $28,9 \%$ của Đồng bằng sông Hồng, 26,4\% của Đông Nam Bộ, $13,0 \%$ của Tây Nguyên [2, tr.15]. Điều này cho thây, chất lượng đội ngũ lao động của vùng đã có sự chuyển biến khá tích cực, song vẫn chưa đáp ứng với yêu cầu phát triển kinh tế- xã hội hiện nay. Chính vì thế, đã tác động không nhỏ đến cơ hội tìm kiếm việc 
làm cũng như thu nhập ổn định của lực lượng lao động của vùng. Đồng thời, sự tăng lên của đội ngũ lao động có trình độ đại học trở lên là sự thay đổi tích cực đối với chất lượng nguồn nhân lực của vùng ĐBSCL. Tuy nhiên, sự tăng lên này khá nhanh sẽ khiến tạo ra một thị trường lao động thừa thầy thiếu thợ nếu không có biện pháp đào tạo và sự dụng lao động phù hợp.

Bảng 2.1. Cơ cấu lao động từ 15 tuổi trở lên chia theo trình độ chuyên môn (\%)

\begin{tabular}{|c|c|c|c|c|c|c|c|c|}
\hline $\begin{array}{l}\text { Trình độ kỹ thuật chuyên } \\
\text { môn }\end{array}$ & 2009 & 2010 & 2011 & 2012 & 2013 & 2014 & 2015 & 2016 \\
\hline $\begin{array}{l}\text { Chưa qua đào tạo và không } \\
\text { có bằng chứng chỉ chuyên } \\
\text { môn }\end{array}$ & 96,4 & 91,7 & 90,7 & 90,8 & 89,5 & 89,6 & 88,4 & 87,9 \\
\hline Sơ cấp nghề & 1,3 & 1,0 & 1,9 & 2,2 & 2,7 & 2,4 & 2,9 & 2,6 \\
\hline $\begin{array}{l}\text { Trung cấp nghề } \\
\text { Trung cấp chuyên nghiệp }\end{array}$ & $\begin{array}{l}0,1 \\
0,8\end{array}$ & $\begin{array}{l}0,7 \\
2,1\end{array}$ & 2,6 & 2,3 & 2,6 & 2,3 & 2,6 & 2,6 \\
\hline $\begin{array}{l}\text { Cao đẳng nghề } \\
\text { Cao đẳng chuyên nghiệp }\end{array}$ & $\begin{array}{l}0,0 \\
1,0\end{array}$ & $\begin{array}{l}0,1 \\
1,1\end{array}$ & 1,1 & 1,1 & 1,2 & 1,2 & 1,4 & 1,5 \\
\hline Đại học trở lên & 0,4 & 2,9 & 3,7 & 3,4 & 4,0 & 4,5 & 4,9 & 5,5 \\
\hline Không xác định & 0,0 & 0,5 & & & & & & \\
\hline
\end{tabular}

(Nguồn: Tổng Cục thống kê. Kết quả điều tra lao động và việc làm từ năm 2009-2016, Hà Nội)

Sở dĩ có sự biến đổi này là vì, người dân ở đây đã thấy được tính tích cực trong việc học tập và nâng cao trình độ chuyên môn của bản thân cũng như con cái của họ. Cho nên, việc đầu tư giáo dục của cha mẹ đối với việc học của con cái có sự biến đổi nhất định. Bằng chứng của cuộc điều tra biến đổi mức sống [3, tr.155] cho thấy, so với năm 2008, việc chi giáo dục, đào tạo bình quân 1 người đi học trong 12 tháng của vùng ĐBSCL năm 2014 tăng lên 2,14 lần. Trong đó, chi cho giáo dục đại học tăng 2,04 lần; chi cho bậc học nghề tăng lên 2,46 lần so với năm 2008 [3, tr.155] . Ngoài ra, sự quan tâm đầu tư cho giáo dục của Trung ương đã góp phần làm thay đổi chất lượng nguồn nhân lực của toàn vùng. Trung ương đầu tư ngân sách cho giáo dục ĐBSCL từ $17,5 \%$ lên $22 \% /$ năm nhằm đáp ứng yêu cầu phát triển giáo dục tại khu vực này trong những năm tới, khắc phục tình trạng tụt hậu về giáo dục-đào tạo ở tại đây. đầu tư xây dựng cơ sở hạ tầng cho giáo dục cũng có sự quan tâm thỏa đáng. Năm học 2013-2014, toàn vùng có 73 cơ sở đào tạo trung cấp chuyên nghiệp (trong đó có 39 trường trung cấp và 34 trường đại học, cao đẳng tham gia đào tạo trình độ trung cấp chuyên nghiệp) tăng 11 cơ sở so với năm học 2010 2011 (riêng thành phố Cần Thơ tăng 5 trường); về mạng lưới trường TCCN tăng 10 trường (tăng $34,5 \%$ so với năm 2010), số các cơ sở giáo dục 04 cơ sở (chủ yếu các bộ ngành xây dựng cơ sở đào tạo trên địa bàn và có một số trường $\mathrm{TCCN}$ được nâng cấp từ TCCN lên cao đẳng) [4]. Có thể nói, việc đầu tư này đã góp phần tích cực vào sự thay đổi trình độ chuyên môn của lực lượng lao động trong vùng hiện nay.

\subsection{Biến đổi cơ cấu xã hội-nghề nghiệp theo loại hình kinh tế}

Bảng số liệu 2.2 cho thấy, sự chuyển dịch cơ cấu xã hội- nghề nghiệp theo loại hình kinh tế của vùng ĐBSCL còn khá chậm và chưa ổn định. Loại hình kinh tế cá nhân/ hộ sản xuất kinh doanh cá thể vẫn còn chiếm hơn $2 / 3$ tổng số lao động có việc làm. Điều này đã phản ánh trình độ phát triển kinh tế của vùng còn mang tính cá thể cũng như chưa thể hiện có sự liên kết với nhau. Đồng thời, loại hình kinh tế tập thể có xu hướng giảm từ $0,6 \%$ của năm 2010 xuống còn $0,2 \%$ của năm 2011 và 2012 và $0,1 \%$ của năm 2016 . Không chỉ vậy, loại hình kinh tế có vốn đầu tư nước ngoài cũng có xu hướng giảm nhẹ 0,1 điểm phần trăm qua các năm 2011,2012; song lại có xu hướng tăng mạnh từ năm 2013 đến 2016. Sở dĩ là vì, khả năng thu hút đầu tư của vùng trong 
những năm trước 2013 dường như còn khá hạn chế. Bằng chứng về thu hút vốn FDI cho thấy, năm 2012, toàn vùng chỉ thu hút được 538 triệu USD từ nguồn vốn đăng ký đầu tư nước ngoài, chiếm $7,4 \%$ so với tổng FDI cả nước, chưa bằng một nửa TP Đà Nẵng hay Hải Phòng. Bởi lẽ, cấu trúc kinh tế của đồng bằng sông Cửu Long "nghiêng" về nông nghiệp. Điều này thật sự rât khó thu hút đầu tư nước ngoài [5]. Tuy nhiên, trong những năm 2013 trở lại đây, ĐBSCL đã phát triển ngành nông nghiệp ứng dụng công nghệ cao và đã tạo ra sức thu hút đầu tư mới đôi với các doanh nghiệp nước ngoài. Theo kết quả của báo cáo Bộ Kế hoạch và Đầu tư, trong 6 tháng đầu năm 2018 vùng ĐBSCL có 4.600 doanh nghiệp (DN) thành lập mới, tăng $8,7 \%$ so với cùng kỳ năm 2017; vốn đăng ký 44.900 tỷ đồng, tăng $45,8 \%$ so với cùng kỳ. Bên cạnh thu hút đầu tư trong nước, 6 tháng đầu năm 2018 , toàn vùng có $7 / 13$ tỉnh, thành phố có dự án đầu tư trực tiếp nước ngoài (FDI) mới với 47 dự án, có vốn đăng ký hơn 800 triệu USD [6]. Chính vì thế, lực lượng lao động tham gia loại hình kinh tế có vốn đầu tư nước ngoài tăng mạnh trong thời gian gần đây.

Bảng 2.2. Cơ cấu lao động từ 15 tuổi trở lên chia theo loại hình kinh tế (\%)

\begin{tabular}{llllllll}
\hline Loại hình kinh tế & 2010 & 2011 & 2012 & 2013 & 2014 & 2015 & 2016 \\
\hline $\begin{array}{l}\text { Cá nhân/ Hộ sản xuất kinh } \\
\text { doanh cá thể }\end{array}$ & 85,9 & 85,0 & 85,4 & 84,6 & 84,4 & 82,9 & 82,1 \\
Tập thể & 0,6 & 0,2 & 0,2 & 0,1 & 0,1 & 0,1 & 0,1 \\
Tư nhân & 6,2 & 6,7 & 6,2 & 6,5 & 6,4 & 8,2 & 8,6 \\
Nhà nước & 5,9 & 6,9 & 7,0 & 7,4 & 7,4 & 6,7 & 6,9 \\
Vốn đầu tư nước ngoài & 1,4 & 1,3 & 1,2 & 1,6 & 1,6 & 2,1 & 2,3 \\
\hline
\end{tabular}

(Nguồn: Tổng Cục thống kê. Kết quả điều tra lao động và việc làm từ năm 2010-2016. Hà Nội)

Ngoài ra, kết quả ở bảng 2.2 còn thể hiện ở chỗ rằng, cơ cấu lao động trong loại hình kinh tế nhà nước tăng lên qua các năm từ 2010 đến 2014 nhưng giảm xuống năm 2015 và tăng trở lại vào năm 2016. Mặc dù biến động qua các năm nhưng loại hình kinh tế này vẫn chiếm tỷ lệ khá cao so với các loại hình kinh tế khác. Điều này cho thấy, loại hình kinh tế nhà nước có sức hút khá mạnh đối với lực lượng lao động ở ĐBSCL. Phải chăng, loại hình kinh tế nhà nước thường có ưu thế hơn các loại hình kinh tế khác như tính ổn định của công việc cũng như việc thực hiện nghiêm chỉnh các chế độ chính sách. Tuy nhiên, vấn đề đặt ra đối với loại hình kinh tế này là doanh nghiệp nhà nước sẽ cồng kềnh hơn và làm tăng gánh nặng cho ngân sách của nhà nước.

So với cả nước, lực lượng lao động theo loai hình kinh tế cá nhân chiếm tỷ lệ cao hơn nhiều so với Đồng bằng sông Hồng $(66,4 \%)$, Đông Nam Bộ (52,7\%); tuy nhiên, vẫn thấp hơn so với các vùng Tây Nguyên $(87,9 \%)$, Trung du và miền núi phía Bắc $(84,0 \%)$. Trong khi đó, lực lượng lao động tham gia loại hình kinh tế tư nhân, vốn đầu tư nước ngoài thì ở ĐBSCL vẫn còn thấp so với các vùng Đồng bằng sông Hồng, Đông Nam bộ [2, tr.96-97]. Mặc dù vậy, tỷ lệ lực lượng lao động tham gia loại hình kinh tế cá nhân ở ĐBSCL đã giảm xuống và tăng lên các loại hình kinh tế khác, ngoại trừ loại hình kinh tế nhà nước. Điều này cho thấy, lực lượng lao động tham gia các loại hình kinh tế có sự khác biệt giữa các vùng.

2.3. Biến đổi cơ cấu xã hội-nghề nghiệp theo vị thế việc làm

Nghiên cứu của tác giả Nguyễn Thị Minh Hòa [4] đã nhận định rằng, cơ cấu xã hội- nghề nghiệp theo vị thế công việc ở Việt Nam hiện nay đã thay đổi theo xu hướng tích cực, giảm tỷ trọng lao động việc làm cho gia đình, tăng tỷ trong lao động làm công ăn lương. Kết quả điều tra lao động và việc làm năm 2016 cũng thống nhất với kết luận trên rằng, so với năm 2009, tỷ trọng lao động cả nước làm công ăn lương tăng 8,7 điểm phần trăm, chiếm khoảng $1 / 3$ tổng số lao động có việc làm. Điều này phản ánh xu hướng tích cực của quá trình chuyển dịch cơ cấu kinh tế [3, tr.19]. 
Bảng 2.3. Cơ cấu lao động từ 15 tuổi trở lên chia theo vị thế vị làm $(\%)$

\begin{tabular}{llllllll}
\hline Vị thế việc làm & 2010 & 2011 & 2012 & 2013 & 2014 & 2015 & 2016 \\
\hline Chủ cơ sở & 4,4 & 3,6 & 3,2 & 2,9 & 2,1 & 3,1 & 3,2 \\
Tự làm & 43,6 & 44,7 & 47,3 & 47,7 & 38,1 & 44,5 & 43,9 \\
Lao động gia đình & 19,6 & 18,5 & 13,1 & 16,6 & 27,7 & 16,1 & 9,8 \\
Làm công ăn lương & 32,3 & 33,2 & 31,5 & 32,8 & 32,1 & 36,2 & 41,1 \\
Xã viên HTX & 0,0 & 0,0 & 0,0 & 0,0 & 0,0 & 0,0 & 0,0 \\
\hline
\end{tabular}

(Nguồn: Tổng Cục thống kê. Kết quả điều tra lao động và việc làm từ năm 2010-2016. Hà Nội)

Tương tự với tình hình biến đổi cơ cấu xã hội- nghề nghiệp theo vị thế việc làm của cả nước, sự biến đồi cơ cấu này ở ĐBSCL diễn ra cũng theo xu hướng lao động gia đình giảm khá mạnh từ $19,6 \%$ của năm 2010 xuống còn $9,8 \%$ của năm 2016, chủ cơ sở cũng có xu hướng giảm xuống 1,2 điểm phần trăm so với 2010. Trong khi đó, tỷ lệ lao động tự làm của năm 2016 tăng lên không nhiều so với năm 2010 (chỉ 0,6 điểm phần trăm) (xem bảng 2.3).

Có thể nói, cơ cấu xã hội- nghề nghiệp theo vị trí việc làm ở ĐBSCL đã có xu hướng biến đổi tương đối tích cực khi mà cơ cấu lao động làm việc cho gia đình đã giảm xuống khá nhanh. Tỷ lệ lao động làm công ăn lương của vùng cũng khá cao so với cả nước, điều này đã thể hiện trình độ phân công lao động, chuyên môn hóa lao động của vùng ngày càng cao và thể hiện sự phát triển của các ngành nghề công nghiệp, dịch vụ trong đời sống kinh tế- xã hội và thị trường lao động của vùng đã có sự phát triển. Tuy nhiên, sự phân hóa và phát triển này chưa ổn định.

\subsection{Biến đổi cơ cấu xã hội-nghề nghiệp theo khu vưc kinh tế}

Chuyển dịch cơ cấu kinh tế theo hướng tăng tỷ trọng lao động công nghiệp và dịch vụ, giảm tỷ trọng lao động nông nghiệp là một trong những chủ trương đúng đắn của Đảng và Nhà nước ta, góp phần thúc đẩy nhanh quá trình công nghiệp hóa, hiện đại hóa của đất nước. Mặc dù vậy, cơ cấu lao động trong nông, lâm và thủy sản của 3 năm qua (2010-2016) ở ĐBSCL vẫn chiếm gần $1 / 2$ tổng số lực lượng lao động. Trong khi đó, lực lượng lao động trong công nghiệp tăng lên 2,6 điểm phần trăm và lao động trong ngành dịch vụ tăng 2,2 điểm phần trăm so với năm 2010 (xem bảng 2.4). So với các vùng của cả nước, tỷ lệ lực lượng lao động trong khu vực công nghiệp, dịch vụ ở ĐBSCL thấp hơn ở Đồng bằng sông Hồng, Đông Nam bộ; ngược lại, nông nghiệp vẫn còn cao (gần $50 \%)$. Cơ cấu lao động ở các ngành tăng giảm không ổn định và tăng không nhiều. Điều này cho thấy, sự chuyển dịch cơ cấu kinh tế ở vùng còn khá chậm và chưa ổn định.

Bảng 2.4. Cơ cấu lao động từ 15 tuổi trở lên theo khu vực kinh tế (\%)

\begin{tabular}{llllllll}
\hline Khu vực kinh tế & 2010 & 2011 & 2012 & 2013 & 2014 & 2015 & 2016 \\
\hline Nông, Lâm, Thủy sản & 52,6 & 51,7 & 52,1 & 49,8 & 50,9 & 49,3 & 47,8 \\
Công nghiệp & 17,3 & 16,8 & 16,6 & 17,0 & 16,7 & 18,6 & 19,9 \\
Dịch vụ & 30,1 & 31,5 & 31,3 & 33,2 & 32,5 & 32,1 & 32,3 \\
Tổng & 100 & 100 & 100 & 100 & 100 & 100 & 100 \\
\hline
\end{tabular}

(Nguồn: Tổng Cục thống kê. Kết quả điều tra lao động và việc làm từ năm 2010-2016. Hà Nội)

Sở dĩ là vì, cấu trúc kinh tế của ĐBSCL vẫn còn chủ yếu là nông nghiệp và hiện nay một số tỉnh trong vùng đang có xu hướng phát triển các ngành du lịch sinh thái, miệt vườn. Hơn nữa, trong những năm gần đây, sức thu hút đầu tư trong và ngoài nước về phát triển công nghiệp đã có xu hướng tăng lên. Chính vì thế, lực lượng lao động vẫn còn tập trung vào lĩnh vực nông nghiệp, một số có xu hướng chuyển sang ngành dịch vụ như du lịch, thương mại và công nghiệp. 
Như vậy, các bằng chứng từ các cuộc điều tra lao động và việc làm đã cho thấy cơ cấu lao động của ĐBSCL có sự biến đổi, song vẫn còn khá chậm và chưa ổn định so với cả nước ở các khu vực kinh tế, vị thế việc làm và loại hình kinh tế. Sự biến đổi này đã phản ánh trình độ phát triển kinh tế- xã hội cũng như khả năng phát triển thị trường lao động của vùng trong những năm gần đây. Chính điều này đã tác động không nhỏ đến sự phát triển kinh tế- xã hội ở ĐBSCL hiện nay.

\section{Tác động của biến đổi cơ cấu xã hội- nghề nghiệp đến phát triển kinh tế ở đồng bằng sông Cửu Long}

Cùng với sự phát triển của cả nước, vùng ĐBSCL đã có những có những thành tích kinh tế đáng kể. Trong giai đoạn 2001-2010, tốc độ tăng trưởng GDP của vùng đạt được $11,5 \%$. Tuy nhiên trong những năm gần đây, đặc biệt là trong 2 năm $(2012,2013)$, tốc độ tăng trưởng kinh tế của vùng tăng chậm lại lần lượt là $11,3 \%$ và $9,0 \%$ [7, tr.65]. Mặc dù vậy, từ năm 2013 trở lại đây, đồng bằng sông Cửu Long đã bắt đầu "sống lại" với thu hút nhiều đầu tư. Đây là dấu hiệu tích cực đáng mừng cho sự phát triển của vùng; song cần phải có chiến lược đảm bảo tính bền vững của nó. Điều này có nghĩa rằng, trong quá trình phát triển, nền kinh tế của vùng ĐBSCL vẫn còn không ít khuyết điểm, ảnh hưởng tới sự tăng trưởng và phát triển bền vững của vùng. Bởi vì, do sự chuyển đổi cơ cấu kinh tế chưa đồng bộ, cơ cấu kinh tế chủ yếu là thuần nông, lực lượng lao động chưa có trình độ chuyên môn cao và môi trường đầu tư còn chậm cải tiến. Chính vì thế, đã dẫn đến sự biến đồi xã hội trong đó có biến đổi cơ cấu xã hội- nghề nghiệp còn chậm và chưa ổn định. Cho nên, sự tác động của biển đổi cơ cấu xã hội- nghề nghiệp đến sự phát triển ở ĐBSCL trên một số khía cạnh như thu nhập, phân tầng xã hội, quyết định di cư...

\subsection{Tác động đến thu nhập và phân tầng xã hội}

Bảng số liệu 3.1 cho thấy, thu nhập bình quân của một người/ tháng ở các lĩnh vực đều tăng lên qua các năm. Điều này cho thấy, đời sống của lao động hoạt động trên các lĩnh vực đã có sự cải thiện hơn. Song, vẫn còn sự khác biệt khá đáng kể về thu nhập bình quân 1 người/ tháng ở khu vực kinh tế. Thu nhập bình quân của 1 người/ tháng ở lĩnh vực dịch vụ cao hơn lĩnh vực nông nghiệp gấp 1,43 lần vào năm 2011 và 1,54 lần vào năm 2016; tỷ lệ này ở lĩnh vực công nghiệp cao hơn so với nông nghiệp là 1,25 lần vào năm 2011 và 1,35 lần vào năm 2016 . Có thể nói, sự khác biệt này đã tạo ra khoảng cách về thu nhập giữa các lực lượng lao động hoạt động trong các lĩnh vực khác nhau và khoảng cách này đang có xu hướng mở rộng hơn giữa các lĩnh vực dịch vụ, công nghiệp với nông nghiệp. Nhìn chung, thu nhập bình quân của một người/ tháng ở ngành nông nghiệp luôn thấp hơn so với các ngành khác, đặc biệt là dịch vụ. Chính vì thế, cơ hội vươn lên làm giàu của lao động ở lĩnh vực nông nghiệp rất ít so với các lĩnh vực công nghiệp và dịch vụ.

Bảng 3.1. Thu nhập bình quân 1 người/ tháng theo khu vực kinh tế (nghìn đồng)

\begin{tabular}{llll}
\hline Khu vực kinh tế & 2011 & 2016 & $\begin{array}{l}\text { Sự chênh lệch } \\
\text { giữa 2016/2011 }\end{array}$ \\
\hline Nông nghiệp & 2014,4 & 2888,0 & 1,43 \\
Công nghiệp và xây dựng & 2508,7 & 3902,8 & 1,56 \\
Dịch vụ & 2883,4 & 4460,2 & 1,55 \\
\hline
\end{tabular}

(Nguồn: Tổng Cục thống kê. Kết quả điều tra lao động và việc làm năm 2011, 2016. Hà Nội)

Không chỉ có sự phân tầng xã hội về thu nhập ở khu vực kinh tế mà còn có sự phân tầng xã hội về thu nhập ở loại hình kinh tế. Bảng số liệu 3.2 cho thấy, thu nhập bình quân 1 người/ tháng của loại hình kinh tế cá nhân là thấp nhất và cao nhất là loại hình kinh tế nhà nước và loại hình kinh tế có vốn đầu tư nước ngoài. Điều này có thể lý giải tại sao cơ cấu lao động ở loại hình kinh tế nhà nước tăng lên ổn định và sự tăng giảm không ổn định của loại hình kinh tế cá nhân/ hộ sản xuất kinh doanh cá thể trong những năm qua. 
Bảng 3.2. Thu nhập bình quân 1 người/ tháng theo loại hình kinh tế (nghìn đồng)

$\begin{array}{llll}\text { Loại hình kinh tế } & 2011 & 2016 & \text { Chênh lệch giữa năm } \\ \text { Cá nhân/ Hộ sản xuất kinh doanh cá thể } & 2066,7 & 3249,0 & 2016 / 2011 \\ \text { Tập thể } & 2493,5 & 3473,8 & 1,57 \\ \text { Tư nhân } & 2925,8 & 4556,3 & 1,39 \\ \text { Nhà nước } & 3202,4 & 5038,3 & 1,57 \\ \text { Vốn đầu tư nước ngoài } & 2822,9 & 4858,0 & 1,72\end{array}$

(Nguồn: Tổng Cục thống kê. Kết quả điều tra lao động và việc làm năm 2011, 2016. Hà Nội)

Như vậy, các bằng chứng thống kê cho thấy, sự biến đổi cơ cấu xã hội- nghề nghiệp đã góp phần làm cho thu nhập của lao động tăng lên, song bên cạnh đó, nó đã tạo phân tầng xã hội về thu nhập ở các loại hình kinh tế, khu vực kinh tế. Do đó, cần có những giải pháp để thúc đẩy sự chuyển dịch cơ cấu xã hội- nghề nghiệp một cách nhanh chóng, góp phần thu hẹp khoảng cách về thu nhập giữa các lĩnh vực, giúp cho lực lượng lao động có thể ổn định cuộc sống tại địa phương của họ.

\subsection{Tác động đến sự quyết định di cu của lao động}

Toàn vùng có khoảng 145,9 nghìn người từ 15 tuổi trở lên di cư vào năm 2016. Trong đó có khoảng 107,8 nghìn người di cư tham gia vào lực lượng lao động. Có nhiều nguyên nhân khiến cho người dân nơi đây quyết định di cư. Đó là ở tại phương, họ rất khó tìm kiếm việc làm để có thu nhập ồn định. Hơn nữa, lực lượng lao động này thường làm nông nghiệp, trình độ thấp. Quá trình đô thị hóa ngày càng nhanh đã thu hẹp diện tích đất nông nghiệp dẫn đến thiếu đất canh tác cho nên họ phải có sự quyết định di cư đến các thành phố lớn để có cơ hội tìm kiếm việc làm, giúp họ thoát nghèo. Ngoài ra, tình trạng xâm nhập mặn ngày càng nghiêm trọng ở ĐBSCL đã khiến cho nhiều lao động phải bỏ ruộng đất, bỏ quê để kiếm cơ hội mới. Trong khi đó, sự chuyển dịch cơ cấu lao động ở khu vực kinh tế diễn ra khá chậm và lực lượng lao động chưa qua đào tạo còn khá nhiều đã khiến cho lực lượng lao động của vùng chưa có thể tìm kiếm việc làm tại chỗ để có thu nhập ổn định cho cuộc sống. Vì thế, nó đã tạo ra lực đẩy lực lượng lao động ở địa phương di cư đến các đô thị lớn với mong muốn tìm kiếm việc làm và cơ hội được đổi đời. Do đó, cần có những giải pháp chuyển dịch tích cực về cơ cấu xã hộinghề nghiệp theo trình độ học vấn, khu vực kinh tế, nghề nghiệp, để lực lượng lao động có thể tìm kiếm việc và thu nhập ở tại địa phương.

\section{Kết luận và khuyến nghị}

Như vậy, việc phân tích thực trạng biến đổi cơ cấu xã hội- nghề nghiệp ở ĐBSCL trong những năm gần đây theo các tiêu chí khác nhau cho thấy có sự thay đổi nhưng vẫn còn chậm và chưa ổn định. Chính điều đó đã tác động đển thu nhập và phân tầng xã hội về thu nhập ở các loại hình kinh tế và khu vực kinh tế; tác động đến sự quyết định di cư của lao động trong vùng. Do đó, để thúc đẩy tốc độ chuyển dịch cơ cấu xã hộinghề nghiệp của ĐBSCL, nghiên cứu gợi mở một số khuyến nghị như sau:

(1) Thực hiện chính sách và chương trình đào tạo nghề cho lực lượng lao động trong vùng, đặc biệt là lao động ở nông thôn, lao động nữ. Bởi vì, việc đào tạo này làm cho trình độ kỹ thuật chuyên lao động trong vùng được nâng lên, giúp cho họ có thể tìm kiếm việc làm tại chỗ, tham gia hoạt động vào các loại hình kinh tế. Có như thế, góp phần thúc đẩy việc chuyển dịch cơ cấu lao động theo hướng tích cực hơn và thu hẹp khoảng cách về thu nhập ở các hoạt động kinh tế. Để thực hiện được điều này, chính sách và chương trình đào tạo cần phải căn cứ vào nhu cầu lao động của vùng, trình độ tiếp thu của lao động...nhằm tránh sự lãng phí trong đào tạo và nâng cao chất lượng đào tạo hơn. 
(2) Cần thúc đẩy mô hình kết 4 nhà cũng như liên kết vùng để phát huy thế mạnh của vùng là lúa gạo, trái cây và thủy sản. Bởi vì, sự liên kết này sẽ tạo mô hình sản xuất khép kín từ người sản xuất ra nguồn nguyên liệu cho đến giai đoạn chế biến và vận chuyển thành phẩm. Cho nên, thực hiện sự liên kết này sẽ làm tăng nhanh các khu chế xuất nông, thủy sản, góp phần làm cho sự chuyển dịch nhanh hơn về cơ cấu xã hội- nghề nghiệp theo khu vực kinh tế và loại hình kinh tế. Khi đó, giải quyết được việc làm cho lực lượng lao động ở địa phương, hạn chế tình trạng lao động địa phương di cư đến các đô thị lớn.

(3) Cần có chính sách khuyến khích và cải thiện môi trường đầu tư để thu hút đầu tư trong nước và quốc tế vào phát triển vùng. Sở dĩ là vì, thu hút và cải thiện môi trường đầu tư sẽ góp phần làm cho đa dạng hóa loại hình kinh tế ở địa phương, giúp cho giải quyết việc làm tại chỗ và chuyển dịch cơ cấu xã hội- nghề nghiệp theo loại hình kinh tế có hiệu quả hơn, tránh làm quá tải cho loại hình kinh tế nhà nước. Đồng thời, góp phần tạo ra cạnh tranh lành mạnh về thu nhập giữa các loại hình kinh tế. Để làm được điều này, cần có thực hiện nghiêm túc chế độ, kiểm tra giám sát về hoạt động của các loại hình kinh tế về thực hiện chế độ cho lao động; thực hiện thủ tục đầu tư gọn và nhanh chóng phù hợp với pháp luật; ưu đãi về đất đai, thuế... và có cam kết về đào tạo và sử dụng lao động của địa phương.

(4) Cần có sự tái cấu trúc lại nền kinh tế của vùng theo hướng bền vững và thích ứng với biến đổi khí hậu, bởi vì hiện nay, cấu trúc kinh tế của vùng chủ yếu là nông nghiệp, cho nên thu hút đầu nước ngoài là một việc làm hết sức khó khăn. Do đó, việc tái cấu trúc lại nền kinh tế của vùng là cần thiết. Để làm được điều này, cần nghiên cứu thế mạnh của từng địa phương để có quy hoạch tổng thể cho vùng, nhằm thực hiện chuyên môn hóa của từng địa phương trong vùng.

Tóm lại, việc phân tích thực trạng về biến đổi cơ cấu xã hội- nghề nghiệp ở ĐBSCL đã cho thấy bức tranh tổng thể về sự biến đổi này cũng như tác động của nó đến phát triển kinh tế- xã hội của vùng. Đồng thời, đã gợi mở ra một số khuyến nghị để chuyển dịch cơ cấu xã hội- nghề nghiệp theo hướng tích cực hơn, góp phần phát triển bền vững ở ĐBSCL trong tương lai.

\section{Tài liệu tham khảo}

[1] Đảng Cộng sản Việt Nam, Văn kiện đại hội Đại biểu toàn quốc lần thứ $\mathrm{X}$. Nxb CTQG, Hà Nội, 2006.

[2] Tổng Cục thống kê, Kết quả điều tra lao động việc làm năm 2016, Nxb Thống kê, Hà Nội, 2017.

[3] Tổng Cục thống kê, Kết quả điều tra mức sống hộ gia đình năm 2014, Nxb Thống kê, Hà Nội, 2016.

[4] Bộ Giáo dục Đào tạo và Bộ LĐTBXH, Báo cáo về phát triển giáo dục, đào tạo và dạy nghề các tỉnh Vùng Đồng bằng Sông Cửu Long giai đoạn 2011 2015, phương hướng phát triển giai đoạn 2016 2020, 2016.

[5] Nhân dân điện tử, Bức tranh kinh tế Đồng bằng sông Cửu Long từ góc nhìn đầu tư nước ngoài, 2013. http://www.nhandan.com.vn/kinhte/nhandinh/ite6,5m/21745102-buc-tranh-kinh-te-dongbang-song-cuu-long-tu-goc-nhin-dau-tu-nuocngoai.html (Truy cập ngày 26/7/2014).

[6] Kinh tế Việt Nam, Đồng bằng sông Cửu Long: Đột phá trong thu hút đầu tư, 2018. http://kinhtevn.com.vn/dong-bang-song-cuu-longdot-pha-trong-thu-hut-dau-tu-33837.html (Truy cập ngày 6/10/2018).

[7] Ngô Anh Tín, Đầu tư công và tăng trưởng kinh tế vùng ĐBSCL, Tạp chí Phát triển và Hội nhập, 15 , 2014. 